aircraft, which cost less and could be costed more accurately, might well result in producing out of date aircraft. These days, Mr Green said, it was no good expecting to sell obsolete equipment. Even the emerging countries were looking for the most modern weapons, and if Britain didn't supply them, somebody else would. It was a sobering thought.

\section{Recreation in the North-East}

THe regional planning problems presented by the diverse development of the North-East coastal areaincluding as it does both the heavily industrial and coal-mining area of Durhsm and the primarily scenic coast of Northumberland-are discussed in a report published this week by the National Parks Commission (The Coasts of North-East England, HMSO, £1 12s.6d.). The report, the seventh in a series of reports on the state of coastal development and preservation, stems from a conference held last year by the Commission with the regional planning authorities at the request of the Minister of Housing and Local Government.

A major problem facing the region is the more than 3 million tons of muck dumped from the six active collieries on to Durham's beaches each year. With half of the county's 25 miles of coast already built up for industrial and urban purposes, the additional 8 miles destroyed by tipping seriously limits the land available for recreational use. The Durham county planning officer stressed the pressing need for the Government to carry out a feasibility study of the various methods of clearing the coast and a cost-benefit analysis of the extent to which such expenditure would be justified.

The various authorities agreed that, because of the great variety of the 138 miles of coastline, the regions concerned must co-ordinate, and share in the expense of developing, the recreational facilities needed to serve the population of the area as a whole. While most of the undeveloped coast south of Northumberland is only suitable for local day-trippers, with figures averaging 50,000 on a fine Sunday in summer, the planning officer from Northumberland estimated that more than 172,000 visitors used the Northumberland coast on a comparable day and that some 130,000 came for annual holidays, spending about $£ 1.6$ million in the county. Since all but the most intensively used facilities would not appeal to private enterprise, the local authorities agreed that they would have to be prepared to take the initiative in providing for public recreation, and only through combined research efforts could the various authorities determine the future needs of the entire North-East. The chairman of the West Hartlepool Town Planning Committee noted that the cost must be spread over a wide area to include those urban centres from which the visitors came as well as the authority meeting the demand.

For a start a working party of the North Regional Planning Committee was reported to be assessing the present and likely future pattern of recreational demand on the region's coast and countryside, and the Northumberland and Durham Travel Association was attempting to determine how the potential for tourism in the area could best be exploited. In any case, it was stressed that the coast cannot be treated as a situation apart, but must be considered in relation to the other problems and priorities of the region.

\section{Parliament in Britain}

\section{by our Parliamentary Correspondent}

\section{Power Stations}

Mr Reginald Freeson, for the Ministry of Power, gave information about dual-fired power stations, which are able to run either on gas or coal. The Central Electricity Generating Board had converted one boiler at Hams Hall power station for experimental purposes. This had established that there were no technical limitations, and the board had applied to the minister for permission to convert the remaining five boilers at the station. The board had also applied for permission to convert the oil-fired South Denes power station to dual firing with gas. While not envisaging general conversion to dual firing, he thought there might be scope for the summer use of natural gas. (Written answers, May 30 and 28.)

\section{Multi-racial Studies}

MR EDwaRd SHORT, Secretary of State for Education and Science, said that the Centre for Multi-racial Studies at the University of Sussex was being supported by the UGC and the Ministry of Overseas Development. The UGC had supplied the accommodation, and the MOD had given a grant of $£ 80,000$ for the establishment of a centre in Barbados. The Social Science Research Council had given $£ 12,469$ for research into "inter-ethnic relationships in Barbados and St Lucia". In the future, it was hoped that the centre might be able to contribute towards an understanding of racial prejudice in schools in Britain. (Written answer, May 30.)

\section{Overseas Development}

Mr Albert Oram, Parliamentary Secretary to the Minister of Overseas Development, said that the ministry was in close touch with the Intermediate Technology Development Group, which supports the development of relatively simple tools and techniques as the best way of helping the underdeveloped countries. The Tropical Products Institute and the overseas liaison unit of the National Institute of Agricultural Engineering were working along similar lines. The ministry also provided a comprehensive scheme of postgraduate studentships, covering agricultural, veterinary and other natural resource subjects. (Oral answers, May 30.)

\section{Post Office}

Mr Roy Mason, Postmaster General, defended the proposal made by the General Post Office to replace the four London telephone directories by thirty-six directories, each covering one borough. If the present system were maintained, the directories would be twice their present size by 1975; already their size was discouraging people from using them, he said. Each of the borough directories would include 5,000 of the most frequently wanted numbers from all over London. Subscribers who wanted directories other than those for their own neighbourhood could have them; they could have the lot if they wanted them. The plan had been discussed with the Post Office Users Council, the Greater London Council, the London Boroughs' Association and the London Chamber of Commerce. It had, he said, received general support. The scheme had not been kept secret, he said; it had in fact been mentioned in the annual accounts of the GPO for last year. (Oral answer, May 30.) 